\title{
Factors in Controlling the Successful Peer Teaching Method in Higher Education
}

\author{
Komm Pechinthorn, Jirangrug Samarkjarn \& Nico Irawan \\ International College of Rajamangala University of Technology Krungthep \\ Bangkok, Thailand \\ (komm.p@mail.rmutk.ac.th)
}

\begin{abstract}
This educational research paper was conducted by using questionnaires to collect the essential student survey data. The source of the study was a chosen mid-sized English for Everyday Use subject of 60 students in a public university under the International College of Rajamangala University Krungthep (ICUTK) in the capital city, Bangkok district in Thailand with the time frame from June to October 2019.The research employed multiple regression equation models by Minitab version 18 to study the structural relationships on satisfactions of peer teaching methodology, meaning that students were required to teach their peers instead of teachers in classroom. The selected variables were gender, GPA, age and attendance of the students. A major contribution of this education research was its significant direct relationship which mediated the method of teacher and student learning by testing the peer teaching methodology in classroom compared to the traditional classroom. Clear descriptive statistics such as mean, standard deviations were provided from the calculation and multiple regressions analysis shows the coefficients, t-stats, errors and significant values of each selected variables. Moreover, the calculation model for those variables was formed for the future prediction for the related educators. The results indicated the importance of peer teaching method in class room for student learning supporting by the highly satisfied scores have impact on all variables included in this research.
\end{abstract}

Keywords: peer teaching; teaching method; students' satisfaction; satisfaction score; English subject.

After 2019, students in Thailand are able to access and purchase smart phone due to its highly competitive market. This leads to an obstacle for teacher in higher education. Current students have an opportunity to use their mobile phones in most of the classrooms.
Without the strict regulations from the teachers, they tend to focus on their multifunction devices rather than the classroom. Therefore, the idea of active learning and how to increase students' engagement in classroom have been brought up to the equation in higher 
education. One of the ways to eliminate the technological focused mobile phones and increase student engagement is through peer teaching. This terminology was defined by Vasay (2010) as a technique in enhancing the students' performance in understanding different concepts in the subject, especially their ability to express their ideas and by Parr et al. (2004) as an effective way in the planning of teaching, lessons demonstration and the analysis of the educational content by students depending on clarity and comprehensiveness. Peer teaching encourages students to assume a more active role in knowledge acquisition of knowledge (De Lisi, 2002). The main reasons for this are that peer teaching basically gives the sense of purpose to the students and makes sure that they actually know what they are reading and learning before transferring to their peers (Saito, 2008). The students are required to thoroughly understand course material and be attentive to details in order to perform it.

The purpose of this research is to identify different factors that have strong impact on the satisfaction score of peer teaching method in the classroom in order to make teachers in any field of education to be aware of and successful in their teachings.

Different academicians and researchers have found many factors on how to improve the student quality in learning on their researches and books such as giving tough assignments (Kuh et al., 2010), increasing the students' motivation (Hasan et al., 2010) applying the electronic media and internet inside the actual classrooms (Harandi, 2015) and implementing the system of rewarding (Brown, 2007). Yet, many others simply use peer teaching method in class to achieve their learning goals. There are both correlational and experimental evidences with appropriate controls for ability to suggest that peer teaching itself can have a vital and positive impact on knowledge retention. It indicates that learning the class materials assigned by teachers to teach other students may particularly be an effective way to increase content mastery (Pascarella and Terenzini, 2005).

According to Akalin (2005), the students' views about peer teaching were relatively positive. They have realized, expressed and found that peer teaching method as an effective and invaluable opportunity which helps them be prepared for their future careers. Brophy (2004) found that increased physical contacts, ability to alter the traditional classroom structure and emotional freedom to teach the classroom were the benefits of peer teaching method. Subramaniam (2006) agrees with benefits of the peer teaching method and states that there is high efficiency of this method in form of having opportunity for students to reflect upon their teaching and expose the realities of teaching. This eventually leads to the development and improvement of their own skills. Reeve and Jang (2006) added fostering a sense of efficiency, promoting mastery orientation and encouraging better participation are included as benefits of running the classroom using peer teaching. In fact, schools and institutions which use peer teaching method have been been known to improve in which the students perform better attitudes towards the subjects, study habits and communication with classmates. In research by Pechinthorn (2017), students prefer learning through peer teaching when compared to traditional method and inform high satisfaction score. They also believe to have more motivation when peer teaching than lecturing by teacher in university classes and would like to face this peer teaching method again in the next semester if possible. Furthermore, there have been reports from the students that peer teaching method helps them in time management, self-reflection and communication skills. (Youdas et al., 2008). Having students work with their peers is an effective method because it is a way to force them to be active learners and to communicate through course concepts in their own words. Moreover, Lord (2001) conducted a research and informed that students who work in groups 
performs better on exams, predominantly in regard to critical thinking and reasoning skills.

Despite the fact that those literatures above identifying the problems, positives and negatives of peer teaching method in their research papers and many of them solely focus on the their outstanding results, it is challenging to identify the vital factors that could lead to the successful of this effective way of teaching. Therefore, this study aimed to identify different factors that have strong impact on the satisfaction score of peer teaching method in the classroom in order to make teachers in any field of education aware of and successful in their teachings.

Apparently, the peer teaching method normally provides benefits and high scores of satisfaction level. However, this research wants to answer the following question;

1) What are the vital factors that have strong impact on the satisfaction score level of peer teaching method in the classroom?

Therefore, this research proposes the following hypotheses.

$\mathrm{H} 0$ : Gender does not have any impact on the satisfaction level of peer teaching method.

H1 : Gender has impact on the satisfaction level of peer teaching method.

H0 : GPA does not have any impact on the satisfaction level of peer teaching method. $\mathrm{H} 2$ : GPA has impact on the satisfaction level of peer teaching method.

$\mathrm{H} 0$ : Age does not have any impact on the satisfaction level of peer teaching method.

H3 : Age has impact on the satisfaction level of peer teaching method.

$\mathrm{H} 0$ : Attendance does not have any impact on the satisfaction level of peer teaching method. $\mathrm{H} 4$ : Attendance has impact on the satisfaction level of peer teaching method.

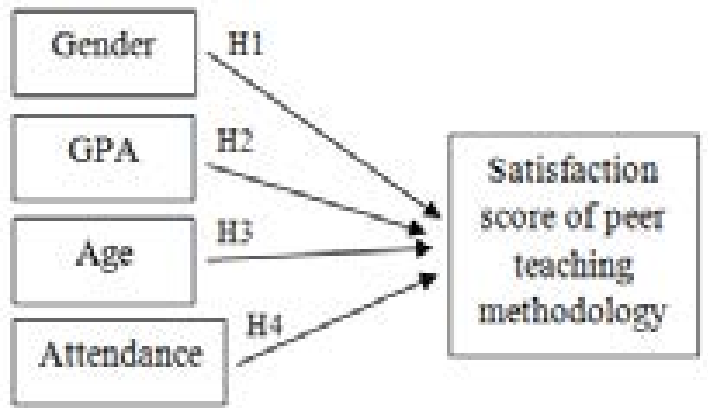

Figure 1. The conceptual framework

\section{Method}

The Participants and Data Collection

The population for this research consisted of 60 students enrolled in a single course offered on the main university campuses of ICUTK. The course only had one teacher while the course content, materials and assistant from the teacher were the same. Prior to collecting data, the researchers obtained permission from the department to collect 3 variables (Gender, GPA and Age of the students) for conducting this research. The last variable to collect was attendance of the student, which was done by the last week of the class. In addition, the most important quantitative data collection, the satisfaction score level of using the peer teaching method was collected in the last week of class through questionnaires.

Third week into a fifteen weeks semester, the five students were assigned into groups of five students and asked to take charge in preparing, running and teaching one hour class session. To ensure the quality, each group has opportunity to separately meet with the teacher outside class before the real teaching. And after the first group taught on the 3rd week, teacher took time to comment, discuss and allow feedbacks from other students about the group materials and peer teaching performance in class.

\section{Measurement and Data Analysis}

Regarding the data collected, they were in form of number, percentage and coding. 
Meanwhile, the data for evaluation of the students' satisfaction of peer teaching have the highest score of 5 with interval scale of 1 to 5,1 as the lowest and 5 as the highest. Once the final week has finished and questionnaires have been filled and collected by the teacher, research assistants would put the data into 5 columns-raw data in the Microsoft Excel for recording purpose, specifically students' satisfaction of peer teaching score, Gender, GPA, Age and Attendance.

Since there are three variables in form of number and one variable in form of category to be tested in the hypotheses above, this research selected to use the regression model function in Minitab version 18 to run the final calculation.

\section{Results and Discussion}

The average score of the 60 students' satisfaction of peer teaching was 4.086 out of 5 which was considered to be very highly satisfied. For GPA, the lowest and highest were 1.95 and 3.70 respectively with the average of 2.968. Since the selected class was for the 3rd and 4th year students, the average of Age was 21.7 years old. For attendance, there were 15 weeks in one subject but students missed classes 2 to 3 times. The average attendance almost reached 13 out of 15 weeks at 12.933 weeks.

From Table 2, the first and only categorical predictor variable was Gender of the respondents has coefficients and $\mathrm{P}$-value at -0.370 and 0.029 respectively. If

Table 1. Descriptive Statistics

\begin{tabular}{|c|c|c|c|c|c|}
\hline \multicolumn{6}{|c|}{ Total number of students: 60} \\
\hline & \multirow{2}{*}{$\begin{array}{l}\text { Minimum } \\
\text { Statistic }\end{array}$} & \multirow{2}{*}{$\begin{array}{l}\text { Maximum } \\
\text { Statistic }\end{array}$} & \multicolumn{2}{|c|}{ Mean } & \multirow{2}{*}{$\begin{array}{l}\text { Std. Deviation } \\
\text { Statistic }\end{array}$} \\
\hline & & & Statistic & Std. Error & \\
\hline Satisfaction of Peer Teaching & 3.80 & 5.00 & 4.0867 & .08482 & .65703 \\
\hline GPA & 1.95 & 3.69 & 2.968 & .07101 & .55007 \\
\hline Age & 20.00 & 25.00 & 21.700 & .21167 & 1.63955 \\
\hline Attendance & 10.00 & 15.00 & 12.933 & .21109 & 1.63507 \\
\hline
\end{tabular}

Table 2. Multiple Regression Analysis by Minitab version 18

\begin{tabular}{|c|c|c|c|c|c|c|}
\hline & \multicolumn{5}{|c|}{ ANOVA } & \\
\hline & $\mathrm{df}$ & SS & MS & $\mathrm{F}$ & $\begin{array}{l}\text { Significance } \\
\mathrm{F}\end{array}$ & \\
\hline Regression & 4.000 & 8.462 & 2.115 & 6.841 & 0.000 & \\
\hline Residual & 55.000 & 17.008 & 0.309 & & & \\
\hline \multirow[t]{3}{*}{ Total } & 59.000 & 25.469 & & & & \\
\hline & \multicolumn{5}{|c|}{ Multiple Regression calculation } & \\
\hline & Coefficients & $\begin{array}{l}\text { Standard } \\
\text { Error }\end{array}$ & t Stat & P-value & Lower 95\% & Upper 95\% \\
\hline Intercept & 3.866 & 1.312 & 2.947 & 0.005 & 1.237 & 6.495 \\
\hline Gender & -0.370 & 0.165 & -2.239 & 0.029 & -0.701 & -0.039 \\
\hline GPA & 0.290 & 0.136 & 2.137 & 0.037 & 0.018 & 0.562 \\
\hline Age & -0.102 & 0.047 & -2.159 & 0.035 & -0.197 & -0.007 \\
\hline Attendance & 0.140 & 0.047 & 2.968 & 0.004 & 0.045 & 0.234 \\
\hline
\end{tabular}


the student is male, his satisfactory score of Peer teaching method would be 0.370 less than female student. The P-value score is 0.029 which is less than the significant level at 0.05 . Therefore, it rejected the hypothesis representing that Gender has effect on the Peer teaching method in class.

Meanwhile, other 3 variables namely GPA, Age and Attendance, were under continuous predictor variables. GPA of the respondents has coefficients and $\mathrm{P}$-value at 0.290 and 0.037 respectively. The P-value score of GPA is less than the significant level at 0.037 . Therefore, it rejected the hypothesis representing that GPA has effect on the Peer teaching method in class. Furthermore, Age of the respondents has coefficients and P-value at -0.102 and 0.035 respectively. The P-value score of Age has similar value with GPA and is less than the significant level at 0.035 . Therefore, it also rejected the hypothesis representing that Age has effect on the Peer teaching method in class. Moreover, Attendance of the respondents has coefficients and P-value at 0.140 and 0.004 respectively. The P-value score of Attendance has similar value with previous 2 continuous predictor variables and is less than the significant level at 0.004 . Therefore, it similarly rejected the hypothesis representing that Attendance has effect on the Peer teaching method in class.

All 4 variables in this research (Gender, GPA, Age and Attendance) had the P-value less of than 0.05 and rejected the null hypothesis regardless of being categorical continuous

Table 3. The Regression Equation

\begin{tabular}{lll}
\multicolumn{2}{l}{ Gender } & \\
\hline 0 & $\begin{array}{l}\text { Satisfaction of } \\
\text { Peer Teaching } \\
\text { for female } \\
\text { students }\end{array}$ & $\begin{array}{l}0.1023 \text { Age }+0.1399 \\
\text { Attendance }\end{array}$ \\
\hline 1 & Satisfaction of & $=3.50+0.290 \mathrm{GPA}-$ \\
& $\begin{array}{l}\text { Peer Teaching } \\
\text { for male stu- } \\
\text { dents }\end{array}$ & 0.1023 Age +0.1399 \\
& Attendance \\
\hline
\end{tabular}

predictor variables in the multiple equation models.

\section{Conclusion}

The respondents of this research appreciated the active peer teaching method when compared to the traditional teachercentered environment by looking at the calculation. Apparently, the satisfaction score of this method was relatively high, yet directly affected with the variables which have been included in the equation. Research objective seeks to identify different factors that have strong impact on the satisfaction score of peer teaching method. Firstly, the vital factor in this research was found to be gender of the students as female students has been proved to prefer this method than male students. GPA was the second vital factor as if the GPA is high, the satisfaction of peer teaching will be higher. In contrast, if the age of the students, the third vital factor, is higher, the satisfaction of peer teaching will be lower.

Besides existing problems in Thailand higher education, procrastination of the students is a common ongoing problem at higher education level. In this case, the attendance cannot be forgiven and was proven to be an impact on the effective peer teaching method which is related to the research by (Akinsola and Tella, 2007). As poor attendance was the factor for the students with poor performance and could result in bad time management throughout the semester between courses. In this research, the class attendance was calculated to be $86.22 \%$ and has been proven to be one of the four vital factors to be successful in peer teaching method in this research.

Even the four variables are included in the consideration of peer teaching, appropriate classroom modification is recommended. It is time consuming and considered to be risky but teacher can do it under the modification strategy with a controllable risk (Velez et al., 2011). 


\section{References}

Akalin, S., \& Suna, A. (2005). Comparison Between Traditional Teaching and Microteaching During School Experience of Student-Teachers. Euroasian Journal of Educational Research, (20), 1-13.

Akinsola, M. K., Tella, A., \& Tella, A. (2007). Correlates of academic procrastination and mathematics achievement of university undergraduate students. Eurasia Journal of Mathematics, Science and Technology Education, 3(4), 363-370. https://doi.org/10.12973/ejmste/75415

Brophy, J. (2004). Motivating students to learn: Second edition. Motivating Students to Learn: Second Edition (pp. 1-418). Lawrence Erlbaum Associates. https:// doi.org/10.4324/9781410610218

Lisi, R. D. (2002). From marbles to instant Messenger: implications of Piaget's ideas about peer learning. Theory into Practice, 41(1), 26-32. https://doi.org/10.1207/ s15430421 tip4101

Harandi, S. R. (2015). Effects of e-learning on Students' Motivation. Procedia Social and Behavioral Sciences, 181, 423-430. https://doi.org/10.1016/j. sbspro.2015.04.905

Afzal, H., Ali, I., Aslam Khan, M., \& Hamid, K. (2010). A Study of University Students' Motivation and Its Relationship with Their Academic Performance. International Journal of Business and Management, 5(4). https://doi. org/10.5539/ijbm.v5n4p80

Kuh, G. D., Kinzie, J., Schuh, J. H., \& Whitt, E. J. (2010). Student engagement: A key to student success. In Student success in college: Creating conditions that matter (pp. 7-21). Jossey-Bass Publishers, Inc.

Lord, T. R. (2001). 101 Reasons for Using Cooperative Learning in Biology Teaching. The American Biology
Teacher, 63(1), 30-38. https://doi. org/10.2307/4451027

Parr, G., Wilson, J., Godinho, S., \& Longaretti, L. (2004). Improving preservice teacher learning through peer teaching: Process, people and product. Mentoring and Tutoring: Partnership in Learning, 12(2), 187-203. https://doi. org/10.1080/1361126042000239938

Pascarella, E. T., \& Terenzini, P. T. (2005). How college affects students: $A$ third decade of research. How College Affects Students: A Third Decade of Research (pp. 534-545). San Francisco, CA: John Willey and Sons, Inc.

Pechinthorn, K. (2017). Increasing student improvement: giving autonomy to students of International College at Rajamangala University of Technology Krungthep in Thailand the complete peer teaching method to their peers in C. International Institute of Social and Economic Sciences. 34th International Academic Conference, Florence, Italy, 13 September, 119-132. https://doi. org/10.20472/iac.2017.034.039

Reeve, J., \& Jang, H. (2006, February). What teachers say and do to support students' autonomy during a learning activity. Journal of Educational Psychology. https:// doi.org/10.1037/0022-0663.98.1.209

Saito, H. (2008). EFL classroom peer assessment: Training effects on rating and commenting. Language Testing, 25(4), 553-581. https://doi. org/10.1177/0265532208094276

Subramaniam, K. (2006). Creating a Microteaching Evaluation Form: the Needed Evaluation Criteria. Education, 126(4), 666-677.

Vasay, E.T. (2010). The Effects of Peer Teaching in the Performance of Students in Mathematics. E-International Scientific Research Journal, 2(2), 161-171. 
Velez, J., Cano, J., \& Whittington, S. (2011). Cultivating Change Through Peer Teaching. Journal of Agricultural Education, 52(1),.40-49. https://doi. org/10.5032/jae.2011.01040

Youdas, J.W., Y., B.L., H., S.R., K., C.M., K., \& J.L., P. (2008). Peer teaching among physical therapy students during human gross anatomy: Perceptions of peer teachers and students. Anatomical Sciences Education, 1(5), 199-206. https://doi.org/10.1002/ase.44 